CONFERENCES AND PROGRAMS DEALING WITH AUSTRIAN HISTORY

\title{
MEETING OF THE PACIFIC COAST BRANCH OF THE AMERICAN HISTORICAL ASSOCIATION \\ AT SAN FRANCISCO, CALIFORNIA, AUGUST 27-29, 1963
}

On the morning of Thursday, August 29, Professor Peter F. Sugar, of the University of Washington, presided over a session on "The Origins of East European Nationalism." All papers dealt wholly, or in large part, with problems of the Habsburg empire between 1790 and 1848 .

Professor George Bárány, of the University of Denver, discussed "The Awakening of Magyar Nationalism." He traced the roots of the movement to the feudal nationalism of the Hungarian nobility but pointed out that, despite isolated earlier manifestations of popular support, modern nationalism originated in opposition to the centralizing and "'germanizing" policies of Joseph II. Although after 1790 the movement changed its emphasis from the maintenance of noble prerogatives to the establishment of an independent nation state, the upper nobility, exemplified by Széchenyi, still retained considerable influence. However, from the 1830's on, the movement, while retaining many of its traditional features, became increasingly socially progressive and liberal, though at the same time more and more uncompromising towards the aspirations of the other nationalities living within the territory of the crown of St. Stephen. At the same time, leadership fell more and more into the hands of the gentry and the middle classes. In conclusion, Professor Bárány deplored the undoubted excesses of Magyar nationalism, but he stressed the fact that, within the context of the period, the growing nationalism betokened the advancement of civilization.

Professor Stephen Fischer-Galati, of Wayne State University, whose paper was read by Professor Sugar, presented his views on "The Origins of Modern Rumanian Nationalism." $\mathrm{He}$ maintained that the Transylvanian Supplex libellus Valachorum of 1790 marked the beginning of the first phase of modern Rumanian nationalism, which lasted until 1848. At the same time, Fischer-Galati stressed the fact that during the nineteenth century Rumanian nationalism developed important differences in the Transylvanian and the Danubian regions. Under Habs- 
burg rule, Transylvanian nationalists were able to press for social reform and for full "nation" status, while under the shadow of Russia, and after 1846, the nationalists in the Danubian principalities, deeply apprehensive about the specter of a peasant revolt, found the achievement of the historic traditions of Latinity and the unification of the various Rumanian areas a safer and more realizable aim. Even so, the nationalists in Walachia maintained a slight interest in social reform; however, in Moldavia the assertion of Latinity as a counterpoise to Russian domination became the overriding factor. The divergences between the different parts of the nationalist movement and the subordination of social reform ideals to an extreme form of Latinism became of crucial importance in the development of Rumanian nationalism after 1848.

The final paper, on "The Origins of Yugoslav Nationalism," was delivered by Professor Ivo J. Lederer, of Yale University. Lederer began with an analysis of the historical forces operating for and against Yugoslav unity. Then he traced the various attempts and endeavors of the Croatian, Serbian, and Slovene national movements which culminated in the failure of the Illyrian dream in 1848-49. Nonetheless, the author concluded, by 1848 the Yugoslav idea had taken firm roots. He asserted that in the long run the frustration of Croatian aspirations within the Habsburg empire and the thwarting of Serbian ambitions in Balkan politics led to a convergence of their separate political interests. In addition, Yugoslavism was "sustained by tangible even if not predominant cultural unity. And in the final analysis, the same centripetal force that affected the Serbs and the Croats engulfed the Slovenes ... and the Montenegrins as well."

Professor Gunther E. Rothenberg, of the University of New Mexico, acted as commentator. He questioned the assumption that modern nationalism originated only towards the end of the eighteenth century and pointed out the Habsburg policies which contributed materially to the maintenance of ties between the various South Slav groups. The commentator found himself in general agreement with the views expressed in the papers, but he asserted that greater emphasis ought to be placed on the influence of outside forces, especially the Habsburg government, on the development of nationalism in Yugoslavia and Hungary. 
He also expressed the view that the role of the Orthodox Church in the development of Rumanian nationalism might have deserved closer attention.

All the participants in the panel agreed that further studies of nationalism in southeastern Europe should place greater emphasis on the interaction of the various nationalisms.

\section{University of New Mexico}

GUNTHER E.ROTHENBERG

\section{THE SOUTHERN HISTORICAL ASSOCIATION MEETING}

\section{AT ASHEVILLE, NORTH CAROLINA, NOVEMBER 7.9, 1963}

William A. Jenks, of Washington and Lee University, gave an address on "The Later Habsburg Concept of Statecraft" at the luncheon meeting of the European section on Friday, November 8. He maintained that the renewal of constitutionalism in the Habsburg monarchy in 1867 conditioned Francis Joseph's behavior as a ruler in European royalty's last great period and raised problems which his heirs, Rudolph and Francis Ferdinand, attempted to answer as they prepared for highest responsibility. Determined to uphold his prerogatives to the end of his reign, the emperor was always on guard against the pretensions of the Liberals while they dominated his cabinets in Austria. When more pleasing nominees served as ministers-president, he was likely to urge a conciliation of the nationalities, increasing popular participation in elections, and social security measures. After 1907 he seemed at last to become the opportunist and drifter that Friedjung and Srbik depicted, but earlier he had demonstrated a capacity for growth and understanding that the very punctiliousness and dryness of his personality did much to obscure.

Rudolph, the devotee of "progress" and the friend of doctrinaire liberalism, seems less "modern" in comparison. He mingled a strong sense of "German mission" with an adoration of the army. To secure allies against "clerical" obscurantism, he was willing to overlook the "magyarization" policies of the Liberal cabinets in Budapest. Francis Ferdinand, a self-proclaimed ultraconservative, deplored universal manhood suffrage in Austria but strongly recommended it in Hungary to break the power of the Magyars, whom he disliked. As Austria's last baroque figure, he probably had not decided upan forceful solu- 